\title{
INTERAKSI SOSIAL KOMUNITAS LOKAL DENGAN PENDATANG DAN PERUBAHAN STRUKTUR KOMUNITAS LOKAL \\ (Studi pada Masyarakat Majemuk di Kawasan Industri Makassar)
}

\author{
Oleh: Andi Agustang; Sulaeman Samad; Andi Asrifan
}

\begin{abstract}
ABSTRAK
Keterlibatan interaksi sosial (hubungan sosial yang dinamis) dalam suatu sistem polietnik, ditelaah dan dianalisis dengan model "contigency linkage", yakni keterkaitan interaksi sosial (hubungan sosial yang dinamis) dengan pemberlakuan nilai dan norma, sistem jaringan medan sosial, dan keberadaan individu kreatif. Model analisis mengenai keterkaitan antara interaksi sosial dengan transformasi struktur merupakan hubungan yang bersifat "stokastik" dengan konsep utama yakni struktur dan fungsi. Kedua konsep ini merupakan komponen dari perspektif fungsional (acuan teori modernisasi) yang diperluas dengan pendekatan jaringan dan sistem berperan dalam menyelusuri masalah perubahan. Metode yang digunakan dalam penelitian ini adalah metode survei deskriptif analitik dan sifat penelitian adalah menerangkan (eksplanation) ditunjang oleh pendekatan kualitatif-kuantitatif yang bertujuan menguji hipotesis penelitian dengan desain korelasi dan uji pengaruh. Unit analisis tingkat pembina adalah pimpinan kecamatan, aparat kelu-rahan, ketua RW, ketua RT, tokoh masyarakat sebagai informasi kunci termasuk tokoh-tokoh komunitas lain yang keseluruhannya berada dan berdomisili di lokasi penelitian. Observasi terbatas maka penarikan sampel berdasarkan teknik proporsional random sampling (pengamatan), wawancara dengan kuesioner dan wawancara bebas (daftar pertanyaan). Analisis data dilakukan dalam dua bentuk, yakni secara kualitatif dan kuantitatif. Hasil telaahan kualitatif dan kuantitatif mengenai pemberlakuan nilai dan norma, sifat sistem jaringan sosial, individu kreatif ternyata berpengaruh nyata terhadap interaksi sosial yang ditunjukkan melalui hubungan yang dinamis. Secara khusus makna pemberlakuan nilai dan norma lebih mengacu pada ciri kepribadian dan nilai moral komunitas lokal. Perlakuan jaringan sosial sejalan dengan rapat longgarnya jaringan lokal yang bermuatan tradisi dan emosional. Oleh karena itu, komitmen terhadap piranti baru selalu diikuti dengan keinginan memelihara tatanan.
\end{abstract}

Key word: interaksi, organisasi, institusi, komunitas, masyarakat dan kebudayaan.

I. Introduction

Pergeseran paradigma struktur pembangunan nasional dewasa ini yang ditunjukkan adanya proses transformasi struktur ekonomi dari dominasi dibidang pertanian terhadap Produk Domestik Bruto ke arah industrialisasi (Sendjaja, 1994: 4), sehingga pemerintah membuka pintu lebar-lebar untuk investasi di luar usaha pertanian. Investasi baru ini berupa investasi dalam pembangunan industri. Penyebaran lokasi industri ke luar Jawa termasuk Sulawesi Selatan diarahkan untuk mendorong pusat-pusat pertumbuhan industri di daerah 
yang potensil untuk dikembangkan sebagai upaya pemerataan kesempatan dan lapangan kerja, dan pemanfaatan sumber daya setempat secara optimal dengan tetap memelihara kelestarian fungsi lingkungan hidup.

Gambaran serba menyenangkan yang demikian, setelah diadakan penelitian ternyata perkembangan teknologi dalam pelbagai industri di Kawasan Industri Makassar belum banyak berperan dalam penyerapan tenaga kerja. Data yang diperoleh dari hasil penelitian pendahuluan penulis sebelumnya menunjukkan bahwa $64 \%$ penduduk kawasan industri (Kelurahan Daya dan Kelurahan Kapasa) bekerja di sektor pertanian, 2,30 \% disektor industri, 12,70 \% di sektor perdagangan, 5,70 \% di sektor jasa, 7,30 \% di sektor angkutan, 7,50 \% di sektor kuli bangunan, 0,20\% di bidang keuangan, dan 0,30 listrik dan gas dan untuk komunitas lokal (penduduk asli daerah Kawasan Industri Makassar). Berdasarkan laporan hasil studi evaluasi lingkungan yang dilaksanakan oleh WALHI (2016 : 45), diperlihatkan bahwa hanya $1,2 \%$ saja dari pekerja yang bekerja di sektor indus

Hagen (1962) mencatat dua syarat pokok bagi transisi ke arah pertumbuhan ekonomi, yakni (1) penyebaran kreativitas secara baik kemampuan memecahkan masalah dan (2) sikap-sikap ke arah kerja teknis manual yang tersalur kepada inovasi dalam teknologi produksi. Karena itu Hagen melacak kehadiran individu kreatif yang bercirikan penolakan tradisi dan menerima peranan-peranan baru. Sejalan dengan pendapat Hagen dan Mc Clelland memilih pertumbuhan ekonomi adalah perkembangan semangat kewiraswastaan dengan titik bahasan pada nilai-nilai kepercayaan dan ideologi.

Hadirnya suatu pembangunan di suatu wilayah yang ditandai dengan pertumbuhan industri, produksi komersial, pasar komersial dan munculnya berbagai kelembagaan baru, sering menimbulkan berbagai hambatan dalam masyarakat lokal. Hal ini membuktikan kekeliruan imperialisme budaya yang terlalu percaya pada model asumsi hypodermic tanpa melihat bahwa kenyataan empirik tidak sepenuhnya dikhotomis dan linier. Karena itu, baik Friedmen Jonathan (1990) maupun Lee (1994) memberikan tekanan pada adanya pembauran antara unsur modernitas dan lokalisme berupa suatu respon budaya lokal terhadap modernitas. Smelser (1964), sejak awal telah berusaha menganalisis hubungan antara pertumbuhan ekonomi dan struktur sosial. Smelser membuktikan implikasi perkembangan teknologi dan urbanisasi di kawasan kegiatan-kegiatan ekonomi, kegiatankegiatan keluarga, sistem nilai, dan struktur stratifikasi. Tegasnya, pembangunan di suatu wilayah bila tidak ditunjang oleh kondisi sosial-kultural sering terhambat oleh struktur komunitas lokal.

Interaksi antar kelompok etnik di Indonesia sudah lama berlaku. Interaksi itu, biasanya menghasilkan suatu akulturasi atau pembauran dan lebih merupakan difusi dari kelompokkelompok yang dominan (Garna, 1987:2). Hal ini menunjukkan bahwa interaksi tersebut terjadi dalam sistem sosial tertentu. Adanya integrasi dalam suatu sistem sosial tertentu, khusus dalam masyarakat heterogen dilihat Furnivall (1944) sebagai suatu sistem sosial polietnik. Analisis tentang interaksi dan pengaturan hubungan antar etnik hendaknya dilihat dari cara berpikir dalam konteks manusia yang berbeda. Di sisi lain, terlihat pula ikatan positif yang menjalin hubungan antar kelompok etnik yang didasarkan atas sifat budaya yang saling melengkapi dan pada akhirnya akan menimbulkan saling ketergantungan atau situasi simbiosis. Pengkajian mengenai masyarakat majemuk mendapat perhatian yang luas 
dari para ahli, dengan berbagai hasil penelitian seperti yang dilakukan oleh Barth Fredrick (1969), dan Evers (1988).

Masalahnya, bagaimana pola kehidupan yang berbeda ini saling mengisi, khususnya kemampuan komunitas lokal dalam mengadaptasi proses perubahan yang terjadi di sekitar mereka sehingga dapat berperan dan berstatus sejajar dengan komunitas pendatang. Berdasarkan hal tersebut, agar masalah yang telah dirumuskan itu menjadi spesifik, perlu dinyatakan dalam bentuk hipotesis penelitian dan sekaligus merupakan pembatasan masalah sehingga ruang lingkup penelitian jelas batas-batasnya.

1. Tingkat pemahaman norma oleh komunitas lokal dalam mengantisipasi pembangunan diperkirakan dapat mempengaruhi interaksi sosial antar komunitas yang ditunjukkan melalui dinamika relasi sosial.

2. Sifat longgarnya jaringan dalam medan sosial komunitas lokal diperkirakan dapat mempengaruhi interaksi sosial antar komunitas yang ditunjukkan melalui dinamika relasi sosial.

3. Sifat individu kreatif diperkirakan dapat mempengaruhi interaksi sosial antar komunitas yang ditunjukkan melalui dinamika relasi sosial.

4. Interaksi sosial antar komunitas yang ditunjukkan melalui dinamika relasi sosial diperkirakan dapat mempengaruhi perubahan struktur komunitas lokal.

II. Research methode

Metode yang digunakan dalam penelitian ini adalah metode survei deskriptif analitik dan sifat penelitian adalah menerangkan (eksplanation) ditunjang oleh pendekatan kualitatifkuantitatif yang bertujuan menguji hipotesis penelitian dengan desain korelasi dan uji pengaruh. Adapun model rancangan (desain) penelitian ini digambarkan dalam hubungan struktural antar variabel sebagai berikut:

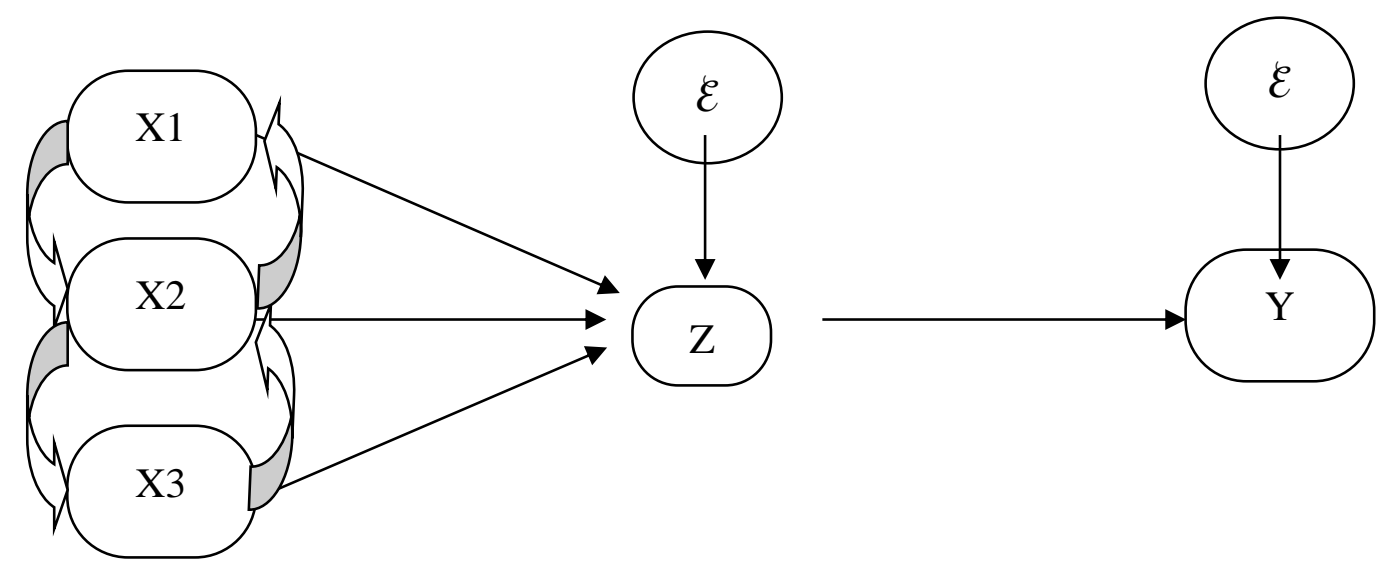

Gambar 3.1. Hubungan Struktural antar Variabel

X1 Tingkat pemahaman terhadap norma sosial

X2 Sifat Suatu Jaringan Sosial

X3 Sifat Individu Kreatif

$\mathrm{Z}$ Interaksi sosial antar komunitas 
Unit analisis tingkat pembina adalah pimpinan kecamatan, aparat kelu-rahan, ketua RW, ketua RT, tokoh masyarakat sebagai informasi kunci termasuk tokoh-tokoh komunitas lain yang keseluruhannya berada dan berdomisili di lokasi penelitian. Observasi terbatas maka penarikan sampel berdasarkan teknik proporsional random sampling (pengamatan), wawancara dengan kuesioner dan wawancara bebas (daftar pertanyaan).

Analisis data dilakukan dalam dua bentuk, yakni secara kualitatif dan kuantitatif. Secara kualitatif lebih diutamakan terutama untuk data yang diperoleh melalui observasi terlibat dan pedoman wawancara. Analisis secara kuantitatif melalui uji statistik terhadap data yang layak untuk dikuantifikasikan, terutama data yang diperoleh dari kuesioner.

\section{Result and disscussion}

1. Tingkat pemahaman norma oleh komunitas lokal dalam mengantisipasi pembangunan diperkirakan dapat mempengaruhi interaksi sosial antar komunitas yang ditunjukkan melalui dinamika relasi sosial.

Hipotesis penelitian yang berbunyi "tingkat pemahan pemberlakuan norma oleh komunitas lokal dalam mengantisipasi pembangunan cenderung mempengaruhi terciptanya interaksi sosial antar komunitas yang ditunjukkan melalui dinamika relasi sosial" diuji berdasarkan paradigma yang disajikan pada bagian metodologi dalam laporan penelitian ini.

Dengan menggunakan data hasil transformasi serta rumus-rumus yang digunakan, maka diperoleh hasil perhitungan $\mathrm{P}_{\mathrm{ZX} 1}=0,0663 ; \mathrm{t}_{\text {hit }}=1,770$ dan $\mathrm{t}_{\mathrm{tab}}=0,9861$. Karena $\mathrm{t}_{\text {hit }}>$ $\mathrm{t}_{\text {tab}}$, maka $\mathrm{H}_{\mathrm{O}}$ di tolak atau $\mathrm{H}_{1}$ diterima atau sering disebut signifikan. Artinya dari parameter struktural antara tingkat pemahan pemberlakuan norma dalam mengantisipasi pembangunan mempunyai pengaruh langsung yang positif terhadap terjalinnya interaksi sosial antar komunitas yang ditunjukkan oleh hubungan yang dinamik antar komunitas sebesar $=0,0044$ atau disimpulkan 0,44\% interaksi sosial yang ditunjukkan oleh hubungan yang dinamik antar komunitas ditentukan oleh tingkat pemahaman pemberlakuan norma, sedangkan sisanya ditentukan oleh variabel-variabel lain di luar dari tingkat pemahaman pemberlakuan norma dalam mengantisipasi pembangunan tersebut. Selanjutnya pengaruh tingkat pemahaman pemberlakuan norma dalam mengantisipasi pembangunan terhadap interaksi sosial yang ditunjukkan oleh hubungan yang dinamik antar komunitas melalui sifat jaringan medan sosial $\left(\mathrm{X}_{2}\right)$ sebesar $0,29 \%$, dan pengaruh tingkat pemahaman pemberlakuan norma dalam mengantisipasi pembangunan terhadap interaksi sosial yang ditunjukkan oleh hubungan yang dinamik antar komunitas melalui sifat individu kreatif $\left(\mathrm{X}_{3}\right)$ sebesar $0,77 \%$. Jadi, jumlah pengaruh tingkat pemahaman pemberlakuan norma dalam mengantisipasi pembangunan terhadap interaksi sosial antar komunitas yang ditunjukkan melalui hubungan yang dinamik antar komunitas baik langsung maupun tidak langsung sebesar 1, $5 \%$.

Sebagai mana dinyatakan bahwa komunitas lokal pada kenyataannya mengalami kondisi yang menunjukkan bahwa di satu sisi masyarakat masuk ke dalam sistem modern, di sisi lain masih tetap berpijak pada budaya feodalisme dan tradisional. Keadaan serupa ini memberikan gambaran suatu kehidupan yang bersifat transisi adalah suatu masyarakat yang sedang menuju masyarakat modern, yaitu post agraris menuju pra industri. Lebih jauh Riggs 
(1964) dalam menyebutnya sebagai suatu masyarakat prismatik. Konsekwensi dari suatu masyarakat prismatik ini hendaknya secara akomodasi dapat membina budaya lokal, di tengah-tengah kehidupan modern. Bahkan menurut Monning Nash (1969) dalam bukunya "Machine Age Maya" bahwa kehidupan tradisional dapat berlanjut dan bahkan berkembang subur pada tingkat yang lebih tinggi di dalam proses industrialisasi. Artinya terciptanya sejenis akomodasi antara pembangunan industri dan komunitas sekitar, sehingga industri maju dengan kegiatan produksinya, dan komunitas sekitar dapat melanjutkan kehidupan dengan institusi-institusi lamanya. Karena itu, seharusnya tidak ada konflik yang melekat antara aspek tradisi dan aspek modern, sehingga tidak ada pernyataan "semakin modern suatu masyarakat semakin perlu masyarakat itu melepaskan tradisinya"

Secara keseluruhan, sistem budaya komunitas lokal yang berfungsi sebagai salah satu elemen penting dan yang dikenal dengan norma (Loomis dan Beegle, 1957), berpengaruh terhadap interaksi sosial yang ditunjukkan melalui dinamika hubungan antar komunitas.

\section{Sifat longgarnya jaringan dalam medan sosial komunitas lokal diperkirakan dapat mempengaruhi interaksi sosial antar komunitas yang ditunjukkan melalui dinamika relasi sosial}

Hipotesis penelitian yang berbunyi "Sifat longgarnya jaringan dalam medan sosial komunitas lokal cenerung mempengaruhi terciptanya interaksi sosial antar komunitas yang ditunjukkan melalui dinamika relasi sosial" diuji berdasarkan paradigma yang disajikan pada bagian metodologi dalam laporan penelitian ini.

Dengan menggunakan data hasil transformasi serta rumus-rumus yang digunakan maka diperoleh hasil perhitungan $\mathrm{P}_{\mathrm{ZX} 2}=0,1485 ; \mathrm{t}_{\text {hit }}=2,0667$ dan $\mathrm{t}_{\mathrm{tab}}=1,6507$ Karena $\mathrm{t}_{\text {hit }}>$ $\mathrm{t}_{\mathrm{tab}}$, maka $\mathrm{H}_{\mathrm{O}}$ di tolak atau signifikan. Artinya dari parameter struktural antara jaringan medan sosial mempunyai pengaruh langsung dan positif terhadap terjalinnya interaksi sosial antar komunitas yang ditunjukkan oleh hubungan yang dinamik antar komunitas sebesar = 0.0220 atau disimpulkan 2,20\% interaksi sosial yang ditunjukkan oleh hubungan yang dinamik antar komunitas ditentukan oleh jaringan medan sosial, sedangkan sisanya ditentukan oleh variabel-variabel lain di luar dari jaringan medan sosial tersebut. Selanjutnya pengaruh jaringan medan sosial terhadap interaksi sosial yang ditunjukkan oleh hubungan yang dinamik antar komunitas melalui norma $\left(\mathrm{X}_{1}\right)$ sebesar $0,29 \%$, dan pengaruh jaringan medan sosial terhadap interaksi sosial yang ditunjukkan hubungan yang dinamik antar komunitas melalui sifat individu kreatif $\left(\mathrm{X}_{3}\right)$ sebesar 3,70\%. Dengan demikian, jumlah pengaruh jaringan medan sosial terhadap interaksi sosial antar komunitas yang ditunjukkan melalui hubungan yang dinamik antar komunitas baik langsung maupun tidak langsung sebesar $6,19 \%$.

Masuknya anggota komunitas ke medan sosial jaringan pasar mampu menghubungkan mereka menuju kehidupan yang disebut "segmentasi dalam tingkat tinggi" atau kehidupan pluralisasi. Artinya, menurut Berger (1974) adanya dikotomi antara kehidupan pribadi dan bidang umum. Kesadaran akan dikotomi ini, berhubungan dengan individu dalam berbagai macam peranan. Kenyataan menunjukkan, perilaku dikotomi 
menurut Berger, atau pemisahan orientasi menurut Parsons, belum sampai terwujud. Malah menurut Soemardjan (1988), pluralisasi ini menimbulkan suatu rasa disorientasi dan kebingungan yang dinamakan "homelessmind". Artinya, sudah ada anggota komunitas lokal yang mengagungkan kehidupan ekonomi di bidang kehidupan lain. Akibat dari keadaan demikian ini, sebagian responden mengalami perubahan gaya hidup, segmentasi ungkapan Poespowardojo (1987) perubahan gaya hidup melalui segi having-nya ketimbang being-nya. Perubahan gaya hidup ini, secara khusus Featherstone (1985) menyebut sebagai "budaya konsumen". Budaya konsumen selalu menonjolkan berbagai unsur antara lain, (1) munculnya ciri-ciri materialistis yang memusatkan kehidupannya pada konsumsi barangbarang, (2) budaya konsumen memberikan tempat 'gaya hidup' sebagai suatu yang istimewa.

Kehidupan dalam medan sosial jaringan kerja memberikan makna tersendiri bagi komunitas lokal. Persepsi terhadap "dunia baru", bertolak dari watak dan ciri kepribadian komunitas, yang mulai terpola menurut tingkatan generasi. Oleh karena itu, tingkat kemampuan dalam menghadapi dan memanfaatkan peluang industri menjadi beragam. Pada umumnya karena ketidak siapan budaya, menyebabkan sebagian komunitas tersingkir dan disingkirkan. Keadaan yang sama dapat dijumpai dari berbagai kasus yang diungkapkan oleh Efendi Noer (1993) maupun Armin (1997). Bagi segelintir warga yang dapat menikmati 'tangan-tangan' perantara, ada yang masih bertahan dan ada pula yang mengundurkan diri. Bagi yang tetap bertahan pada umumnya di kalangan generasi yang lebih muda yang mulai beradaptasi dengan lingkungannya. Berbeda halnya yang mengundurkan diri. Mereka ini justru menyatakan lebih baik mati kelaparan daripada bekerja di bawah suruhan dan perintah orang lain.

\section{Sifat individu kreatif diperkirakan dapat mempengaruhi interaksi sosial antar komunitas yang ditunjukkan melalui dinamika relasi sosial.}

Hipotesis penelitian yang berbunyi "keberadaan sifat individu kreatif dalam komunitas lokal cenderung membepengaruhi terciptanya interaksi sosial antar komunitas yang ditunjukkan melalui dinamika relasi sosial" diuji berdasarkan paradigma yang disajikan pada bagian metodologi dalam laporan penelitian ini.

Dengan menggunakan data hasil transformasi serta rumus-rumus yang digunakan maka diperoleh hasil perhitungan $\mathrm{P}_{\mathrm{ZX} 3}=0,3731 ; \mathrm{t}_{\text {hit }}=5,1617$ dan $\mathrm{t}_{\mathrm{tab}}=1,6507$. Karena $\mathbf{t}_{\text {hit }}>$

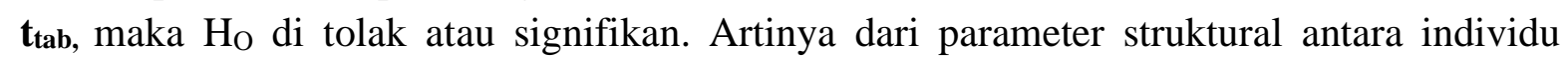
kreatif mempunyai pengaruh langsung yang positif terhadap terjalinnya interaksi sosial antar komunitas yang ditunjukkan oleh hubungan yang dinamik antar komunitas sebesar $=0,1392$ atau disimpulkan $13,92 \%$ interaksi sosial yang ditunjukkan oleh hubungan yang dinamik antar komunitas ditentukan oleh sifat individu kreatif, sedangkan sisanya ditentukan oleh variabel-variabel lain di luar dari sifat individu kreatif tersebut. Selanjutnya pengaruh sifat individu kreatif terhadap interaksi sosial yang ditunjukkan oleh hubungan yang dinamik antar komunitas melalui norma $\left(\mathrm{X}_{1}\right)$ sebesar $0,77 \%$, dan pengaruh sifat individu kreatif terhadap interaksi sosial yang ditunjukkan oleh hubungan yang dinamik antar komunitas melalui jaringan medan sosial $\left(\mathrm{X}_{2}\right)$ sebesar 3,70\%. Dengan demikian, jumlah pengaruh 
jaringan medan sosial terhadap interaksi sosial antar komunitas yang ditunjukkan melalui hubungan yang dinamik antar komunitas baik langsung maupun tidak langsung sebesar $18,39 \%$. Pengaruh variabel lain terhadap $\mathrm{Z}$ diluar variabel $\mathrm{X}_{1}, \mathrm{X}_{2}$, dan $\mathrm{X}_{3}$ sebesar = $73,92 \%$.

Karena itu, pertumbuhan ekonomi dan teknologi secara bertahap dan melalui proses yang cukup panjang. Inovasi tidak hanya membutuhkan teknologi ekonomi, tetapi juga dengan teknologi sosial. Dan proses itu berkenan dengan individu kreatif yang menciptakan sejenis hubungan sosial khusus. Dari pendekatan dan konsep di atas, indikasi teknologi sosial atau individu kreatif adalah: (1) penolakan terhadap tradisi, (2) siap menerima ide dan pengalaman baru, (3) partisipasi dalam media massa yang tinggi, (4) memiliki motivasi kerja yang tinggi. Pelacakan terhadap teknologi sosial ini sama seperti variabel lainnya, yakni melalui pengukuran terhadap setiap indikator yang telah dirumuskan melalui atau berdasarkan tanggapan atas beberapa pernyataan.

Sikap dan perilaku menolak tradisi, lebih mengacu ke pernyataan Kohl (1968) bahwa; "adalah mungkin banyak orang menjadi modern pada sedikit nilai, tetapi tradisional pada yang lain-lain. Oleh karena itu, pemahaman terhadap tradisi (dalam arti penolakan) tidak sampai meliputi seluruh aspek kehidupan. Menolak tradisi, hanya terbatas pada nilainilai yang dapat membatasi ruang gerak individu. Nilai-nilai yang dianggap dapat membatasi ruang gerak individu meliputi: 1) meng-agungkan hidup sederhana; 2) berwatak merendah diri; 3) pelestarian nilai paternalistik.

4. Interaksi sosial antar komunitas yang ditunjukkan melalui dinamika relasi sosial diperkirakan dapat mempengaruhi perubahan struktur komunitas lokal.

Hipotesis penelitian yang berbunyi “interaksi sosial antar komunitas yang ditunjukkan melalui dinamika relasi sosial cenderung mempengaruhi perubahan struktur komunitas lokal" diuji berdasarkan paradigma yang disajikan pada bagian metodologi dalam laporan penelitian ini.

Dengan menggunakan data hasil transformasi serta rumus-rumus yang digunakan maka diperoleh $\mathrm{P}_{\mathrm{YZ}}=0,1027 ; \mathrm{t}_{\mathrm{hit}}=1,6780$ dan $\mathrm{t}_{\mathrm{tab}}=1,6506$. Karena $\mathrm{t}_{\mathrm{hit}}>\mathrm{t}_{\mathrm{tab}}$, maka $\mathrm{H}_{\mathrm{O}} \mathrm{di}$ tolak atau signifikan. Artinya dari parameter struktural antara interaksi sosial yang ditunjukkan oleh hubungan yang dinamik antar komunitas mempunyai pengaruh langsung yang positif terhadap perubahan struktur komunitas sebesar $=0,010553$ atau disimpulkan $1,06 \%$ perubahan struktural ditentukan oleh interaksi sosial yang ditunjukkan oleh hubungan yang dinamik antar komunitas, sedangkan sisanya ditentukan oleh variabelvariabel lain di luar dari interaksi sosial yang ditunjukkan oleh hubungan yang dinamik antar komunitas tersebut. Pengaruh variabel lain terhadap $\mathrm{Y}$ diluar variabel $\mathrm{Z}$ sebesar = 98,94\%. Berbagai pergeseran dan perubahan yang muncul dalam komunitas lokal merupakan sebagian dari pengaruh interaksi sosial antar komunitas yang ditunjukkan melalui dinamika relasi sosial. Perubahan peranan yang diikuti pergeseran pola hubungan, memberikan suasana ke arah orientasi baru di berbagai bidang kehidupan.

Keseluruhan perubahan ini terjadi di antara berbagai budaya, khususnya di kalangan budaya lokal. Keseluruhan perubahan ini akhirnya akan mengarah pada suatu kehidupan yang terintegrasi secara utuh. Bagi komunitas lokal (sebagai hasil temuan penelitian ini) 
berawal dari upaya penyesuaian mental dan perilaku terhadap situasi sosial yang obyektif (di luar dirinya). Usaha adaptasi terhadap sistem yang lebih luas merupakan inti dari permasalahan integrasi. Integrasi menuntut suatu sikap dan pandangan serta pola hubungan yang harmonis dari dan antar pelaku-pelakunya sehingga terciptanya homogenitas pada pola nilai-nilai dan norma di antara kelompok dan struktural yang ada.

Diakui oleh Nimkoff (1960) bahwa proses untuk menciptakan keserasian dan homogenitas itu bukanlah suatu proses yang berjalan cepat dan lancar karena ia adalah suatu proses mental yang berkaitan dengan sikap dan pandangan yang dilandasi oleh kebudayaan masing-masing. Sejalan dengan itu, seperti pendapat Sorokin (1957); Parsons (1973), melihat integrasi sebagai "interaksi dari berbagai pola kebudayaan akan berkisar pada nilai budaya, norma dan adat istiadat dari berbagai sistem.

Mengenai pengaruh antar variabel penelitian seperti yang telah diuraikan dalam bab pembahasan secara lengkap dapat kita lihat pada gambar berikut.

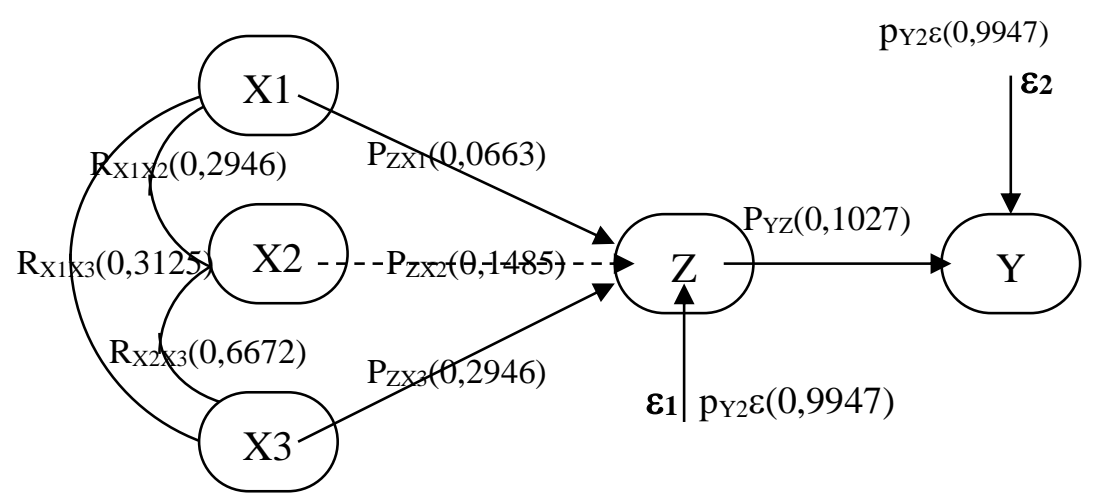

Gambar Pengaruh Antar Variabel Secara Lengakap

\section{Conclusion}

Memperhatikan hasil pembahasan dan pengujian hipotesis, maka dapat ditarik kesimpulan sebagai berikut:

1. Pergeseran pemahaman terhadap pemberlakuan norma ternyata berpengaruh nyata terhadap sikap kompromi, toleransi dan proses kerjasama. Dan malah dapat berperan sebagai "mekanisme" melawan konflik. Pergeseran tersebut terbatas pada nilai dan norma yang keberadaannya dapat membatasi ruang gerak individu.

2. Pergeseran terhadap nilai dan norma memberi peluang adanya "loose structure" di kalangan komunitas lokal. Pola jaringan teritorial yang ditandai pola hubungan yang bersifat "close knit" cenderung bergeser ke arah "loose knit" khususnya terhadap komunitas lain. Struktur yang semakin longgar dapat dilihat dari indikator pola kunjungmengunjungi, pola pinjam meminjam, pola pertukaran dan pola mengundang makan. Sebagian besar responden khususnya dari kelompok generasi muda tidak setuju lagi pada hubungan yang hanya terbatas pada lingkungan sendiri. 
3. Inovasi dalam kehidupan ditentukan oleh teknologi ekonomi dan teknologi sosial. Proses ini berkaitan dengan keberadaan individu kreatif. Munculnya individu kreatif merupakan bagian dari dukungan nilai dan norma serta perluasan jaringan sosial. Secara khusus hal ini dibuktikan dengan sikap terhadap pola hubungan diadik vertikal yang semakin longgar.

4. Secara nyata berpengaruh positif dalam menciptakan hubungan yang dinamik melalui interaksi sosial antar komunitas yang terkonfigurasi pada sikap toleransi, kompromi dan kerjasama. Berdasarkan respon tersebut, membuktikan proses interaksi sosial antar komunitas yang ditunjukkan melalui dinamika relasi sosial berpengaruh nyata dan positif terhadap perubahan struktur komunitas lokal khususnya dalam ruang lingkup penyederhanaan struktural komunitas lokal sebesar 1,06\% (lihat hasil uji hipotesis empat)

Saran yang diajukan berdasarkan kesimpulan adalah:

1. Menyikapi adanya pergeseran pemahaman nilai dan norma dalam diri komunitas lokal, berarti menciptakan suatu kondisi yang siap untuk bertindak sebagai suatu entitas. Pada belahan lain, perlu pula dijaga tradisi dan adat istiadat sebagai jati diri suatu komunitas.

2. Perubahan kehidupan teritorial ke jaringan pasar dan jaringan kerja berarti sebagian komunitas lokal telah mampu beradaptasi terhadap tuntutan dan tantangan pembangunan. Oleh karena itu kegiatan dalam masyarakat secara luas tidak saling menghalangi, bahkan saling mendukung.

3. Kehidupan "baru" pada jaringan kerja menuntut suatu sikap impersonal dan perilaku rasional. Namun demikian perlu kebijakan yang mampu menciptakan seperangkat kepercayaan, simbol, nilai dan sentimen yang berbeda-beda itu dapat hidup bersama. Hal ini secara sosiologis dapat disebut sebagai masalah ketergantungan fungsional atau seperti seringkali disebut sebagai masalah integrasi sistem

4. Mengingat respon budaya (komunitas) lokal lebih bersifat menjaga batas-batas, maka diharapkan pemegang teraju kekuasaan tidak terjebak pada pemikiran "determinisme teknologi". Perlu disusun suatu program yang tetap bernuansa pada kultur lokal dengan berwawasan modernitas.

5. Berdasarkan tingkat perkembangan berbagai aspek fisik, sosial, ekonomi daerah yang cenderung bergeser dari kehidupan "rural" ke "urban", maka penelitian ini dapat ditindak lanjuti, khususnya mengenai konsekwensi-konsekwensi terhadap perkembangan yang mengarah ke kota kecil.

V. Acnowledgment

Daftar Pustaka

Adi Rianto dan Heru Prasodja, 1991, Langkah-langkah Penelitian Sosial, Arcan, Jakarta

Alattas, SH, 1988, Mitos Pribumi Malas, Penerbit Fajar Bakti SDN. BHD, Kuala Lumpur.

Arikunto, Suharsimi, 1992, Manajemen Penelitian Rineka Cipta. Jakarta 
Blau, Peter M. 1986. Exchange and Power in Social Life. London Transaction Publishers.

Brannen Julia, 1997. Mixing Methods : Qualitative and Quantitative Research, Terjemahan N. Nuktah Ar. Fawic Kuede, Pustaka Pelajar Offset Jakarta

Cistensen. A. James; Jerry W. Robinson, 1980. Community Dvelopment in America. Iowa: The Iowa State Univ. Press.

David C. Mc. Clelland, 1961. The Achieving Society. New York: Free Press 1964, Business Drive and National Achievment, Dalam Social Change (ed) Amital Etzoni, New York, Basic Book.

Evers-Hans Dieter, 1980. Teori Masyarakat, Proses Peradaban Dalam Sistem Dunia Modern, Yayasan Obor, Jakarta

Garna, Judistira K. 1987. "Pembauran dan Batas-batas dalam Interaksi Antar Etnik" Makalah Pertemuan Ilmiah Esensi Interaksi Sosial Budaya Dalam Pembangunan Bangsa , Program Pascasarjana, Unpad, Bandung.

Bandung.

1992. Teori-Teori Perubahan Sosial, Program Pascasarjana, Unpad, 1996. Ilmu-Ilmu Sosial Dasar - Konsep - Posisi, Program Pascasarjana, Unpad Bandung.

Gertz, Hilder, 1981. Aneka Budaya dan Komunitas di Indonesia, YIIS \& FIS UI

Gillin and Gillin, 1954. Cultural Sociology. The Mac Millan New York.

Gouldner, Alvin W., 1959 "Reciprocity and Autonomy in Functional Theory", Llewellyn Groos, (ed) Simposium in Sociological Theory. New York, Harver \& Row

Gouldner, Alvin W., 1960, “The Norm of Reciprocity” Amerircan Sociological Review. Vol. 25. April

Guilford. J.P. 1954. Psychometrik Methods ; Kogakusha. Co. Ltd. Tokyo

Homans. C. George, 1960, "Social Behavior": HS Elementary Forms, New York: Harcourt, Brace

Hagen, 2012, Personality and Personal Growth (7th Edition) 7th Edition, The Amazon Book Review

Irawan, Soehartono, 1995. "Metode Penelitian Kualitatif”, Gramedia, Jakarta

Johannesen, Richard L, 1996, Ethics in Human Communication (Third Edition), Editor Dedy Djamaluddin dan Deddy Mulyana, Rosada Group, Bandung.

Johnson. Doyle Paul, 1990. Teori Sosiologi Klasik dan Modern (terj)., Gramedia Jakarta Jilid I dan II

Karl Max dan Fredrick Engels, 1953. Selected Corresponde" Moscow, Foreign Language Publishing House

Kerlinger, Fred N, 1973. Foundations of Behavioral Research, (Terj.) New York, Holt Rinehart and Winston.

Kimbal Young and Mack. W. Reymond, 1965. Principles of Sociology : A Reader in Theory in Research, 3rd ed, NY American

Kohl, Joseph 1968, The Measuriement of Modernism" Austin: The University of Texas Press 
Layendercke, L., 1986. Tata Perubahan dan Ketimpangan. Suatu Pengantar

Louer H. Robert, 1989. Perspektif Tentang Perubahan Sosial, Alih Bahasa: Alimandan, Bina Aksara, Jakarta

Lee, Raymon LM, 1994. Modernization, Postmodern, and The Third World. Current Sociology, 42 (2)

Lerner, Daniel., 1964. The Passing of Traditional Society, Clencoe, Free Press.

Levy Marion J., 1952. The Structure of Society, Princeton NJ, Princeton University Press.

Malinowski Bronislaw, 1944. A Scientific Theory of Culture and Other Essays", New York, Oxford University Press

Marcel, Mauss, 1954. Alih Bahasa Inggeris I Gunnison The Giff. London, Cohen \& West

Mc. Clelland, David, 1961. The Achieving Society. New York: Free Press , 1961.Business Drive and National Achievement, Dalam Social Change, (ed) Amital Etzoni, New York, Basic Book

Merton, Robert K., 1968. Social Theory and Social Structure, Enlarged Eddition. New York. Pree Press

Moore, Wilbert E. 1968. Indication of Social Change. Concept and Measurements New York: Russel Sage Pondation.

Polama Margaret, 1984. Sosiologi Kontemporer (terj) LP3ES. Jakarta.

Rahardjo, Dawam. 1990. Transformasi Pertanian, Industrialisasi dan Kesempatan Kerja. UI - Press

Redfield, Robert. 1956., Pesant.. Society and Culture. University of Chicago Press

Rusidi, 1989. Filsafat Ilmu dan Metodologi Penelitian.: Program Pascasarjana Universitas Padjadjaran, Bandung.

Sendjaja, P. Tuhpawana. 1994. Peranana Perguruan Tinggi Dalam Optimalisa-si Pendayagunaan Sumber Daya Pemuda dan Wanita Melalui Pengembangan Agribisnis. Pidato Pengukuhan/Orasi Ilmiah Jabatan Guru Besar Dalam Ilmu Ekonomi Pertanian Universitas Padjadjaran, Bandung.

Simmel, George, 1955. Conflict and The Web Of Group. Aplications, Translated by Kurt H. Wolf and Reinhard Bendix. New York: Free Press

Sitepu, SK. Nirwana, 1994. Analisis Jalur, FMIPA-UNPAD, Bandung.

Theodorson A George, 1953. Acceptance of Industrialization and Its Affendant Consequence for the Social pattern of non-western Society. American Sociological Review.

Tonnies Ferdinand, 1963. "Serangkai Bunga Sosiologi”, Rajawali Jakarta.

Weber Max, 1947. The Methodology of Social Science, Edited and Translated by Edward A. Shils and Henry A. Finich. New York; Free Press.

Weber Max, 1930. The Protestant Ethic and The Spirit of Capitalism, Translated by Talcot Parsons, New York; Scribners

Wolf, Alison dan Wallace, Ruth A 1973, Contemporary Sociological Theory: Continuing The Classical Tradition. Englewood Cliffs N.J.: Prentice-Hall Inc.

Lain-Lain : 
Bappeda Tingkat II Kotamadya Ujung Pandang, Kumpulan Artikel Penelitian, 1990 dan 1996, Ujung Pandang

Walhi, 1996, Laporan Hasil Evaluasi Lingkungan, Ujung Pandang

Ma'na, P., Agustang, A., Salusu, J., Ikhsan, A., \& Dirawan, G. D. (2015). Decision making strategic value based local wisdom Tongkonan North Toraja. Man India, 95(3), 633-639.

Upe, A., Salman, D., \& Agustang, A. (2019). The effects of the exploitation of natural resources towards risk society construction in Southeast Sulawesi Province, Indonesia. Journal of Degraded and Mining Lands Management, 6(2), 1587.

Awaru, A. O. T., Idris, R., \& Agustang, A. (2018, October). Sexual Education at High School Sinjai East. In 1st International Conference on Social Sciences (ICSS 2018). Atlantis Press.

Idris, M., Ramli, M., Agustang, A., \& Kesuma, A. I. (2015). Bureaucracy Ethics Based in Public Service Local Wisdom in Gowa. Mediterranean Journal of Social Sciences, 6(6 S4), 419-419.

Agustang, A., Pada, A. T., \& Bastiana, M. (2018, October). Social Interaction of Local Communities With Migrants and Changes in The Structure of Local Communities (Study on Plural Society in Makassar Industrial Area). In 1st International Conference on Social Sciences (ICSS 2018). Atlantis Press.

Wardah, S., Salman, D., Agustang, A., \& Fahmid, I. M. (2017). The Contestation of Organic and Non-Organic Agricultural Knowledge in Sustainable Agriculture. Mediterranean Journal of Social Sciences, 8(2), 245-245.

Agustang, A. (2018). SIMBOLIKHAJI: Studi Deskriptif Analitik pada Orang Bugis. AlQalam, 15(2), 317-334.

Pannyiwi, R., Agustang, A., Kasnawi, T., Pada, A. T., Yani, A., \& Syam, S. (2020). Social Network for Drug Circulation in Sidenreng Rappang Regency, Indonesia. Systematic Reviews in Pharmacy, 11(9), 575-577.

Agustang, A., \& Soelthan, A. (2015). Analysis of the Inhibiting Factors of Transparency in the Implementation of Local Governance. Mediterranean Journal of Social Sciences, 6(6 S4), 464.

Nain, U., \& Agustang, A. (2020). Analysis On The Utilization Of Village Funds In Cash For Work Program In Bulukumba Regency, South Sulawesi Indonesia. International Journal of Advanced Science and Technology, 29(7s), 2811-2818.

Azis, F., Idris, R., \& Agustang, A. (2017). Involution Fisheries: Post-Study Model of National Program in Integrated Movement at Community Fishermen's Village Development Arungkeke, Jeneponto. Mediterranean Journal of Social Sciences, 8(1), 441.

Agustang, A. D. M. P., \& Nur, H. (2020). Konflik Mahasiswa Parang Tambung Universitas Negeri Makassar. Phinisi Integration Review, 3(1), 46-54.

Rasyid, R., Agustang, A., Maru, R., Agustang, A. T. P., \& Sudjud, S. (2020). PENYULUHAN PENCEGAHAN PENYALAHGUNAAN NARKOBA DI 
KALANGAN PELAJAR SMP NEGERI 6 DUAMPANUA KABUPATEN PINRANG. JMM (Jurnal Masyarakat Mandiri), 4(2), 116-123.

Rahmania, S., \& Agustang, A. (2017). PRESEPSI MAHASISWA FIK TERHADAP PENYIMPANGAN SEKSUAL LESBIAN (STUDI KASUS PADA MAHASISWA FIK UNM). JURNAL SOSIALISASI, 162-168.

Ashar, A., \& Agustang, A. (2020). Dampak Sosial Dana Desa Dalam Kesejahteraan Masyarakat Di Desa Kalola, Kecamatan Maniangpajo, Kabupaten Wajo. Jurnal Sosialisasi: Jurnal Hasil Pemikiran, Penelitian dan Pengembangan Keilmuan Sosiologi Pendidikan, (1), 19-25.

Yusuf, M., \& Agustang, A. (2020). DINAMIKA PERUBAHAN SOSIAL EKONOMI PADA MASYARAKAT KINDANG KABUPATEN BULUKUMBA. Jurnal Sosialisasi: Jurnal Hasil Pemikiran, Penelitian dan Pengembangan Keilmuan Sosiologi Pendidikan, (2), 31-37.

Fransina, M., \& Andi, A. (2019). THE ANALYSIS OF EXISTENCE OF MIGRATION IN THE CONTEXT OF BASUDARA COMMUNITY IN AMBON CITY, INDONESIA. Russian Journal of Agricultural and Socio-Economic Sciences, 94(10).

Usman, A., Agustang, A., Djalal, D., \& Annas, S. (2018, October). The Contribution Of Supporter Community In Maximizing Their Role For The Advancement Of Makassar Football Club (PSM). In 1st International Conference on Social Sciences (ICSS 2018). Atlantis Press.

Agustang, A., \& Oruh, S. Factors affecting of heropnam of mental disorders in Dadi Regional Hospital in South Sulawesi Province. Man In India, 97(11), 233-244.

Pratiwi, E. L., \& Agustang, A. (2018). PERSEPSI ORANGTUA SISWA TERHADAP TINDAKAN GURU DALAM MENDISIPLINKAN SISWA DI SMK YPKK LIMBUNG. JURNAL SOSIALISASI, 6-10.

Asri, A., Kasnawi, T., \& Agustang, A. Actors' Social Tensions on Traditional Birth Attendants and Midwife Partnerships in Childbirth Assistance (Sociology of Health Study in Bulukumba Regency).

Bahri, S., Kasnawi, T., Agustang, A., \& Adam, A. (2017). Vegetarian Community Social Movement (Analysis of Health Sociology in Makassar). The Social Sciences, 12(10), 1824-1831.

Djalante, A., Agustang, A., Tahmir, S., \& Sahabuddin, J. A Disadvantaged Tribe in Bajoe Village, Bone Regency: A Phenomenological Research on Bajo Tribe's Social Life in Bone Regency, South Sulawesi.

Rahmawati, R., \& Agustang, A. (2018). PERBANDINGAN POLA ASUH ORANG TUA SISWA BERPRESTASI DENGAN SISWA YANG TIDAK BERPRESTASI DI SMA NEGERI 2 GOWA. JURNAL SOSIALISASI, 115-119.

Agustang, A. (2018). PERAN WALI KELAS DALAM PENYELESAIAN KONFLIK ANTAR SISWA DI SMA NEGERI 1 PINRANG. JURNAL SOSIALISASI, 12-16.

Irnawaty, I., \& Agustang, A. (2019). SMARTPHONE ADDICTION PADA MAHASISWA PENDIDIKAN SOSIOLOGI FAKULTAS ILMU SOSIAL UNIVERSITAS NEGERI MAKASSAR. JURNAL SOSIALISASI, 41-46. 
Zainuddin, M., \& Agustang, A. (2019). KONTROL SOSIAL ORANGTUA TERHADAP PENGGUNAAN SMARTPHONE PADA REMAJA (STUDI DI DESA GIRINGGIRING KECAMATAN BONTONMPO KABUPATEN GOWA. JURNAL SOSIALISASI, 68-73.

Sofyan, Y., \& Agustang, A. (2018). PENERAPAN MODEL PEMBELAJARAN KOOPERATIF TIPE NHT (NUMBERED HEADS TOGETHER) TERHADAP

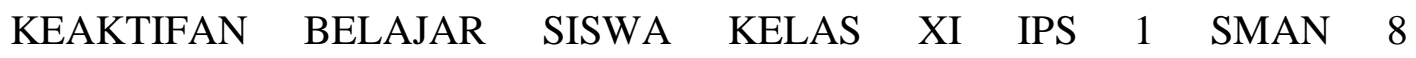
MAKASSAR. JURNAL SOSIALISASI, 158-165.

Agustang, A. (2018). PENERAPAN PUNISHMENT DALAM MEMBENTUK KARAKTER DISIPLIN SISWA DI SMA NEGERI 1 TAKALAR. JURNAL SOSIALISASI, 126-130.

Amiruddin, T. K., Agustang, A., \& Idris, R. (2014). RELIGIOUS CONVERSION IN MARRIED LIFE IN MAKASSAR, THE CASE OF CHRISTIANITY TO ISLAM. JOURNAL OF ACADEMIC RESEARCH, 6(6), 264.

Machmuddin, H., Agustang, A., Kahar, F., \& Bustan, N. (2015). IMPROVING THE QUALITY OF PRIMARY HEALTH SERVICES IN THE PERSPECTIVE OF PARTICIPATORY GOVERNANCE. International Journal of Academic Research, 7(1).

Agustang, A., \& Sahabuddin, J. (2020, October). MODEL KOLABORASI SOSIAL PENDIDIKAN KARAKTER DI SEKOLAH SWASTA KECAMATAN BISSAPPU KABUPATEN BANTAENG. In PROSIDING SEMINAR DAN DISKUSI PENDIDIKAN DASAR.

Astinah, A., Idris, R., \& Agustang, A. (2020). AGILE LEADERSHIP AND DIVORCE EDUCATION: STUDY ON WOMEN'S PERCEPTION. Humanities, 8(3), 323330.

Muis, I., Agustang, A., \& Adam, A. (2020). Elderly Poverty: Social Demographic, Work Distribution, Problem Health \& Social Protection. Asian Journal of Social Sciences \& Humanities Vol, 9(1).

Agustang, A. (2020). Symbolic Violence towards Students in the Context of the Existence of the Stereotypical Frames of Lecturers and Students in the Higher Education System in Indonesia. PalArch's Journal of Archaeology of Egypt/Egyptology, 17(2), 249-258.

Asrifan, A. (2009). Using songs in teaching English language for the young learners. ParePare: unpublished.

Puasa, K., Asrifan, A., \& Chen, Y. (2017). Classroom Talk in Bilingual Class Interaction. Research in Pedagogy, 7(1), 106-121.

Nadirah, N., Tahir, M. H., \& Asrifan, A. (2019). THE ABILITY TO TRANSLATE ENGLISH PHRASES INTO INDONESIAN AND THE DIFFICULTIES FACED $\begin{array}{llllll}\text { BY THE ELEVENTH } & \text { GRADE } & \text { STUDENTS } & \text { OF } & \text { SMAN } & 1\end{array}$ PANCARIJANG. JOURNAL OF ADVANCED ENGLISH STUDIES, 2(1), 41-46.

Apdy, A. P. R., \& Asrifan, A. (2019, April). The Chinese mime game in teaching vocabulary on EFL classroom. In PROCEEDINGS OF THE 65th TEFLIN INTERNATIONAL CONFERENCE (Vol. 65, No. 01). 
Taslim, T., Asrifan, A., Chen, Y., \& Nurdania, N. R. (2019). CORRELATION BETWEEN STUDENT'S VOCABULARY MASTERY AND SPEAKING SKILL. JOURNAL OF ADVANCED ENGLISH STUDIES, 2(2), 65-76.

Muthmainnah, M., Asrifan, A., Al Yakin, A., \& Sahabuddin, C. (2019, April). The use of dictogloss technique on ELT classroom: An experiment study of students listening comprehension. In PROCEEDINGS OF THE 65th TEFLIN INTERNATIONAL CONFERENCE (Vol. 65, No. 01).

Mutmainnah, M., Azis, S., Maulidya, U., \& Asrifan, A. (2017). Glory Style in Mandar Song Lyrics: A study of Mandar Tribe in South Sulawesi, Indonesia. JOURNAL OF ADVANCES IN LINGUISTICS, 8(1), 1286-1291.

Asrifan, A., Rinantanti, Y., Tang, S., \& Nadirah, N. (2019). THE 3-DIMENSION PICTURES IN INCREASING THE STUDENTS ABILITY AND INTEREST TO WRITE DESCRIPTIVE COMPOSITION. JOURNAL OF ADVANCED ENGLISH STUDIES, 2(1), 19-30.

Asrifan, A., Nadira, N., \& Haedar, H. (2018). IMPROVING STUDENTS'READING COMPREHENSION OF DESCRIPTIVE TEXT THROUGH COLLABORATIVE MURDER. JOURNAL OF ADVANCED ENGLISH STUDIES, 1(2), 21-31.

Asrifan, A. (2015). Analysis of English Students' Learning Style in Bilingual Class. International Journal of Literature and Arts, 3(4), 34.

Farahdiba, S., \& Asrifan, A. (2016). Speaking Ability and Psychological Barriers of the Second Year Students of Hotel Department of SMKN 1 Sidenreng Kabupaten Sidrap in Speaking English. Asian EFL Journal, (89), 41.

Asrifan, A. (2012). Increasing the Students Ability to Write Descriptive Composition at SMP Negeri 13 Parepare by using the 3-Dimension Pictures.

Tang, S., Asrifan, A., Chen, Y., Haedar, H., \& Agussalim, M. (2019). THE HUMOR STORY IN TEACHING READING COMPREHENSION. JOURNAL OF ADVANCED ENGLISH STUDIES, 2(2), 77-87.

Nurwanti, N., Asrifan, A., \& Haedar, H. (2019). THE APPLICATION OF COOPERATIVE LEARNING: JIGSAW II TECHNIQUE IN IMPROVING STUDENTS'READING COMPREHENSION OF EXPOSITORY TEXT. JOURNAL OF ADVANCED ENGLISH STUDIES, 2(1), 31-40.

Asrifan, A. (2016). The Effectiveness of Think-Pair-Share Technique in Improving Studentsâ€TM Speaking Ability and Interest. English Literature and Language Review, 2(3), 24-35.

Asrifan, A., Muthmainnah, M., Al-Yakin, A., Sahabuddin, C., \& Haedar, H. (2018). THE CAUSE-EFFECT TECHNIQUE IN TEACHING RECOUNT WRITING. JOURNAL OF ADVANCED ENGLISH STUDIES, 1(2), 63-72.

Asrifan, A., Vargheese, K. J., Syamsu, T., \& Amir, M. (2020). ESP COURSE DESIGN: THE NEED ANALYSIS ON TOURISM DEPARTMENT IN INDONESIA VOCATIONAL HIGH SCHOOLS. JOURNAL OF ADVANCED ENGLISH STUDIES, 3(2), 69-77. 
Asrifan, A., Ghofur, A., \& Azizah, N. (2020). Cheating Behavior in EFL Classroom (A Case Study at Elementary School in Sidenreng Rappang Regency). OKARA: Jurnal Bahasa dan Sastra, 14(2), 279-297.

Nadirah, N., Asrifan, A., Vargheese, K. J., \& Haedar, H. (2020). INTERACTIVE MULTIMEDIA IN EFL CLASSROOM: A STUDY OF TEACHING READING COMPREHENSION AT JUNIOR HIGH SCHOOL IN INDONESIA. JOURNAL OF ADVANCED ENGLISH STUDIES, 3(2), 131-145.

Muthmainnah, A. R., Atmowardoyo, H., Salija, K., \& Asrifan, A. (2020). Literary Work as Teaching Materials: A Study of Students and Lecturers Needs Analysis. Solid State Technology, 63(5), 394-407.

Tilome, A. A., Agustang, A., Jasruddin, M. S., \& Asrifan, A. (2020). Social Exchange of Political Elites in the Regional Leader Election of Gorontalo Province, Indonesia. Solid State Technology, 63(5), 521-531.

Pacinongi, A., \& Asrifan, A. (2020). Bimbingan Pengawas Berkelanjutan dalam Mewujudkan Pendidikan Karakter Bangsa dalam Kegiatan Belajar Mengajar Penjaskes. Celebes Education Review, 2(1), 1-7.

Gunawan, G., \& Asrifan, A. (2020). Penerapan Kerja Kelompok Kegiatan MGMP Guru Ekonomi dalam Menyusun RPP untuk Meningkatkan Kompetensi Pedagogik. Celebes Education Review, 2(1), 31-36.

Yusuf, I., \& Asrifan, A. PENINGKATAN AKTIVITAS KOLABORASI PEMBELAJARAN FISIKA MELALUI PENDEKATAN STEM DENGAN PURWARUPA PADA SISWA KELAS XI IPA SMAN 5 YOGYAKARTA. Editorial Team, 32.

Al Yakin, A., Sahabuddin, C., Rahayu, A., Fitrah, N., \& Arifin, M. (2020). Political Celebrification and Electability: A Study of Political Phenomena Imaging in Election Polewali Mandar District, West Sulawesi, Indonesia. Solid State Technology, 63(5), 632-646.

Junaedah, S. B. T., \& Ahmad, M. A. (2020). The Outdoor Learning Modules Based on Traditional Games in Improving Prosocial Behaviour of Early Childhood. International Education Studies, 13(10).

Octaberlina, L. R., \& Muslimin, A. I. (2020). Efl students perspective towards online learning barriers and alternatives using moodle/google classroom during covid-19 pandemic. International Journal of Higher Education, 9(6), 1-9.

Octaberlina, L. R., \& Anggarini, I. F. (2020). Teaching vocabulary through picture cards in Islamic Elementary School: a case study in Nida Suksa School, Thailand. Jurnal Madrasah, 13(1), 26-38.

Octaberlina, L. R. (2016). Plagiarism in English language theses in Indonesia. Jurnal Ilmu Pendidikan, 14(3).

Octaberlina, L. R., \& Anggarini, I. F. (2020). Teaching vocabulary through picture cards in Islamic Elementary School: a case study in Nida Suksa School, Thailand. Jurnal Madrasah, 13(1), 26-38.

Asrifan, A., Zita, C. T., Vargheese, K. J., Syamsu, T., \& Amir, M. (2020). THE EFFECTS OF CALL (COMPUTER ASSISTED LANGUAGE LEARNING) TOWARD THE 
STUDENTS'ENGLISH ACHIEVEMENT AND ATTITUDE. JOURNAL OF ADVANCED ENGLISH STUDIES, 3(2), 94-106.

Asrifan, A. (2021). ACADEMIC WRITING. LawArXiv. January, 2. https://doi.org/10.31228/osf.io/x2s7e

Asrifan, A. (2020). TUTORIAL PENGGUNAAN QUIZIZZ (www. quizizz. com) PADA PEMBELAJARAN. https://doi.org/10.31219/osf.io/kqnza

Asrifan, A. (2021). Abd Ghofur.“. THE USE OF READING CIRCLES IN INCREASING STUDENTS SPEAKING ABILITY AT THE ELEVENTH GRADE SMK NEGERI, 1. https://doi.org/10.31219/osf.io/8vjxy

Asrifan, A. (2020). Pandemic, Humanity and Education. https://doi.org/10.31219/osf.io/q2gpk

Asrifan, A. (2021). USING CAT AND MOUSE GAME TO IMPROVE STUDENT'S SPEAKING ABILITY AT THE ELEVENTH GRADE OF MA YMPI RAPPANG. https://doi.org/10.31219/osf.io/phtvn

Asrifan, A., \& Ghofur, A. (2021). THE USE OF READING CIRCLES IN INCREASING STUDENTS SPEAKING ABILITY AT THE ELEVENTH GRADE SMK NEGERI 1 PANCARIJANG. https://doi.org/10.31219/osf.io/8vjxy

Asrifan, A. (2021). Book Review: Halliday. 1989. Spoken and Written Language. Oxford University Press. https://doi.org/10.31219/osf.io/ej8tb

Asrifan, A., \& Ghofur, A. (2021). TALK, ACTION, SILENCE, INTERRUPTION AND THEIR IMPLICATIONS IN BUGINESE SOCIETY (SOPPENG REGENCY). https://doi.org/10.31219/osf.io/pv3ku

Asrifan, A. (2020). PENILAIAN BERBASIS ANDROID MENGGUNAKAN APLIKASI PLICKERS. https://doi.org/10.31219/osf.io/htreq

Sapulette, A. A., Agustang, A., \& Syukur, M. Actor Construction in the Frame of Diversity to Achieve Social Harmony in the Life of Tamilouw Village Society Seram IslandMaluku.

Amiruddin, T. K., Agustang, A., \& Idris, R. (2014). RELIGIOUS CONVERSION IN MARRIED LIFE IN MAKASSAR, THE CASE OF CHRISTIANITY TO ISLAM. JOURNAL OF ACADEMIC RESEARCH, 6(6), 264.

Machmuddin, H., Agustang, A., Kahar, F., \& Bustan, N. (2015). IMPROVING THE QUALITY OF PRIMARY HEALTH SERVICES IN THE PERSPECTIVE OF PARTICIPATORY GOVERNANCE. International Journal of Academic Research, 7(1).

Agustang, A., \& Sahabuddin, J. (2020, October). MODEL KOLABORASI SOSIAL PENDIDIKAN KARAKTER DI SEKOLAH SWASTA KECAMATAN BISSAPPU KABUPATEN BANTAENG. In PROSIDING SEMINAR DAN DISKUSI PENDIDIKAN DASAR.

Mutiara, I. A., Agustang, A., Adam, A., Upe, A., \& Equatora, M. A. (2020). The dynamics of prostitutes lives in metropolitan cities. Journal of Critical Reviews. https://doi. org/10.31838/jcr, 7, 165 . 
Haulussy, R. H., Najamuddin, I. R., \& Agustang, A. D. M. P. (2020). The sustainability of the Sasi Lola tradition and customary law (Case study in Masawoy Maluku, Indonesia). Intl J Sci Technol Res, 9(2), 5193-5195.

Agustang, A. (2020). Symbolic Violence towards Students in the Context of the Existence of the Stereotypical Frames of Lecturers and Students in the Higher Education System in Indonesia. PalArch's Journal of Archaeology of Egypt/Egyptology, 17(2), 249-258.

Agustang, A. (2015). Dasar-Dasar Filsafat Penelitian Untuk Pengembangan Ilmu.

Agustang, A. T. P. Muh. Said, dan Rusman Rasyid. 2015. Perkembangan Peran Jender Dalam Prespektif Teori Androgini, 1-8.

Rasyid, R., Agustang, A., Agustang, A. T. P., Bastiana, B., \& Najamuddin, N. Analisis Faktor Yang Mempengaruhi Status Kemiskinan Rumah Tangga Pada Wilayah Central Bussiness District (CBD) di Kota Makassar. Majalah Geografi Indonesia, 34(1), 43-52.

Asmi, A. S., Kasnawi, M. T., Agustang, A., \& Yani, A. (2020). Sociocultural Transformation in Efforts to Reduce Mortality of Infants in Bone Regency, Indonesia. Systematic Reviews in Pharmacy, 11(10), 762-765.

Agustang, A. (2020, October). Social Actions of Galla Actors in the Kaemba Maros Traditional Village Community Sulawesi Selatan. In 3rd International Conference on Social Sciences (ICSS 2020) (pp. 748-753). Atlantis Press.

Agustang, A. (2020). The Symbolic Violence Towards Private School Students Through The Frame Stereotype In Bantaeng District Of Indonesia. Prosiding ICoISSE, 1(1), 578-588.

Ariani $^{1}$, A. I., Agustang, A., Adam, A., \& Alimsyah, S. (2020). INSTITUTIONAL FAILURES IN THE WORLD OF EDUCATION IN SCHOOLS FOR CHILDREN VICTIMS OF PARENTS. Asian Journal of Social Sciences \& Humanities Vol, 9, 2 . 